\title{
Media Independence And Dividend Policy: Evidence From Emerging Stock Markets
}

\author{
Omar Farooq, Aalborg University, Denmark \\ Salma Dandoune, Al Akhawayn University, Ifrane, Morocco
}

\begin{abstract}
Can media pressurize managers to disgorge excess cash to shareholders? Do firms in countries with more independent media follow different dividend policies than firms with less independent media? This paper seeks to answer these questions and aims to document the relationship between media independence and dividend policies in emerging markets. Using a dataset from twenty three emerging markets, we show a significantly negative relationship between dividend policies (payout ratio and decision to pay dividend) and media independence. We argue that independent media reduces information asymmetries for stock market participants. Consequently, stock market participants in emerging markets with more independent media do not demand as high and as much dividends as their counterparts in emerging markets with less independent media. We also show that press independence is more important in defining dividend policies than TV independence. Furthermore, our results show that the relationship between media independence and dividend policies is more pronounced in firms that generate greater interest from investors.
\end{abstract}

Keywords: Media Independence; Dividend Policy; Corporate Governance; Emerging Markets

\section{INTRODUCTION}

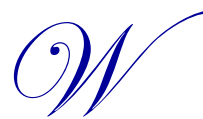

hy do firms headquartered in certain countries pay higher dividends than otherwise similar firms headquartered in certain other countries? Are corporate dividend policies affected by the extent of information asymmetries faced by stock market participants? Given that information asymmetry is a major market imperfection, relationship between the extent of information asymmetries and dividend policy has attracted significant attention in prior literature (Bhattacharya, 1979; Miller and Rock, 1985; John and Williams, 1985). For example, La Porta et al. (2000), while trying to relate country-specific information environment with dividend policies, document higher payout ratios for firms headquartered in common law countries relative to firms headquartered in civil law countries. ${ }^{1}$ They argue that common law countries have stronger investor protection laws, thereby making expropriation costly for managers and insiders. As a result, managers and insiders are forced to pay higher dividends in common law countries. A competing strand of literature, however, suggests that dividends are paid to reduce information asymmetries. Therefore, in countries, where information asymmetries are high, firms are forced to pay dividends to establish reputation as firms that treat their minority shareholder decently. Myers (2000), for example, argues that when governance and investor protection mechanisms are weak, outside investors prefer high dividends. ${ }^{2}$

An important factor that has been overlooked in the prior literature is how independence of media country-specific proxy for information asymmetry - affects dividend policies of firms. Media is a channel though

\footnotetext{
${ }^{1}$ There is vast amount of literature that related firm-specific measures of information asymmetry to dividend decisions made by firms. Kowalewski et al. (2007), for example, document importance of firm-specific proxies for information asymmetries by reporting higher dividend payout ratios for large and more profitable firms. Larger and profitable firms, usually, attract more investor interest and therefore have lower information asymmetries.

${ }^{2}$ If the managers of a firm know more about firm than outside investors, then dividends may signal some of that information to outside investors. Dividend increase allows firms with improved prospects to signal the good news to investors, while dividend decreases force firms to signal bad news. Similarly, no change in dividend signals that a firm's prospects have not changed. Therefore, dividends signal information and are important in reducing information asymmetry.
} 
which information is communicated and disseminated to wider audience. Effective and independent media plays an important role in reducing information asymmetries by making people aware of the events happening around them. Consequently, an independent media addresses the principal-agent problem and establishes a process of accountability for forces in power. Given media's role in reducing information asymmetry, it is worthwhile to see whether it impacts dividend policies of firms. This paper is an attempt to fill this gap by documenting the relationship between the two.

This paper argues that one of the channels via which media independence exercises its influence on dividend policy is through its impact on firm's information environment. Using a large dataset from twenty three emerging markets, we document a significantly negative relationship between media independence and dividend payout ratios. Our results show that for every unit increase in media independence, dividend payout ratio goes down by 11.2611 units. We argue that countries with more independent media have better information environment than countries with less independent media. As a result, firms headquartered in countries with more independent media have lower need to use dividends as a mechanism to establish reputation as firms that treat their minority shareholders decently. Our arguments are consistent with prior literature that suggests that if the likelihood of expropriation is low, firms do not feel the need to use dividends as information asymmetry reducing device (Myers, 2000). This strand of literature predicts lower payout ratios for firms with better information environment. This paper argues that independent media reduces information asymmetries for stock market participants. Therefore, stock market participants in emerging markets with relatively more independent media do not demand high dividends as much as their counterparts in emerging markets with relatively less independent media. Our results are robust for our second proxy for dividend policy - decision to pay dividend or not. We report that odds of paying dividends by firms headquartered in countries with relatively more independent media are 0.0789 times less than firms headquartered in countries with relatively less independent media. We argue that media, on one hand, relieve firms from the need of making reputation and, on the other hand, strengthen shareholder rights by ensuring that no unscrupulous behavior by management is unnoticed. As a result, dividend policy as an information asymmetry reducing device matters less in countries with more independent media, thereby resulting in lower payout ratios and lower likelihood to pay dividends.

In addition, we also show that both - press and TV - exert their effect on dividend policies of firms in emerging markets. However, impact of press independence on dividend policies of firms is relatively stronger than impact of TV independence. Our result is consistent with prior literature that considers press as more developed medium of information dissemination in emerging markets (Afrobarometer, 2003). Furthermore, we also provide evidence that media exerts its influence on dividend policies of only those firms that are likely to attract interest from stock market participants. We, for instance, show that media influences dividend policies of only those firms that are audited by one of the big-four auditors. Our results show no impact of media independence on dividend policies of firms that are audited by smaller auditors. Consistent with the above finding, we also show that dividend policies of firms with bigger size, higher analyst following, more tangible assets, and concentrated ownership are affected by media independence. ${ }^{3}$ Bigger size, higher analyst following, more tangible assets, and concentrated ownership are the factors that can proxy for the interest of stock market participants in firms. ${ }^{4}$ The relation between media independence and dividend policies seem to be weaker in firms with smaller size, lower analyst following, less tangible assets, and dispersed ownership. We argue that media expends its resources only on those firms that are more likely to be followed by stock market participants, thereby minimizing its impact on those firms that are not on the radar of potential investors.

\footnotetext{
${ }^{3}$ There are two schools of thoughts regarding ownership concentration and the interest that a firm generates from stock market participants. On one hand, concentrated ownership provides incentives to insiders and controlling shareholders to expropriate resources out of firm (entrenchment effect). This school of thought suggests that stock market participants may shy away from firms with concentrated ownership. On the hand, there is a plenty of literature that argues that concentrated ownership is a mean to reduce agency conflicts between managers and shareholders. In emerging markets, where enforcement mechanisms are weak, it is advisable to concentrate ownership to monitor management (alignment effect).

${ }^{4}$ Analysts are the service providers. Therefore, they will follow those firms more that generate more interest from investors. On the same note, bigger firms are more visible and therefore have more following from stock market participants. Same arguments can be provided for firms with more tangible assets. We believe that it is relatively difficult to misreport information for firms that have more tangible assets. Anticipating more reliable information, stock market participants may prefer these firms over those firms that have less tangible assets.
} 
This study has implications for investors planning to diversify their portfolios across emerging markets. Our results imply that international portfolio investors should not treat dividend policies in isolation as a proxy for governance environment of firms in emerging markets. Low dividends in some emerging markets may be due to the fact that independent media made information environment so transparent that dividends as an information asymmetry reducing device become less important. Therefore, care should be observed while using dividend policies as a proxy for corporate governance mechanisms in emerging markets.

The paper is structured as follows: Section 2 briefly discusses motivation and background for this study. Section 3 discusses the data used in this study. Section 4 presents assessment of the relationship between dividend policy media independence. Section 5 discusses our results and the paper end with Section 6 where we present our conclusions.

\section{MOTIVATION AND BACKGROUND}

How does media independence affect dividend policy of a firm? This paper argues that media influences dividend policy of a firm via its impact on firm's governance and information environment. Recent strand of literature documents a strong link between governance and information environment of a firm and media. Dyck and Zingales (2002), for example, consider media as an important channel via which managers and directors can be pressurized to act in the best interest of shareholders. They cite couple of examples where media acted as a lever to influence management to enforce corporate governance mechanisms. For instance, they draw attention to a case of SK Telecom, a profitable Korean firm, which used transfer pricing to hide information and benefit those firms that were owned by its Chairman and his relatives. In order to curtail the above mentioned practice, a media campaign was started in the Financial Times. The campaign not only included publishing advertisements in newspapers but also aired advertisements in television and radio. Responding to the pressure from media, firm's directors agreed to restrain transfer pricing and improve corporate governance practices. In another related study, Kahan and Rock (2007) regard media as one of the most important tools via which hedge funds force firms to adopt better governance practices. They believe that bringing some of the corporate governance violations to media attention can discipline management. Dyck et al. (2007) compliment the findings of Kahan and Rock (2007) by showing that the coverage of corporate governance violations in media increases the probability that these violations be reversed.

Above strand of literature identifies couple of channels through which media plays its role as a disciplining device. The most important being its effect on reputation of managers and firms. Fama (1980) argues that manager's future wages are an increasing function of shareholders' and future employers' beliefs about whether a manager will attend to their interests in situations where they cannot be monitored. Fama and Jensen (1983) note that the concerns regarding future monetary consequences can lead managers to act in the interest of shareholders. This strand of literature claims that management reduces its efforts to expropriate not because of the fear of legal actions but due to the concern for their reputation. For reputation to reduce expropriation, the information about unscrupulous behavior of management must be publicized in the media. Zingales (2000) considers publicizing management's deceitful behavior as one of the most powerful disciplining device. Prior literature highlights a number of examples to elaborate the disciplining role of media. For example, the Wall Street Journal published an ad with a full-page picture of a silhouette of the Board of Directors of Sears Roebuck with the title: the "non-performing assets of Sears". The ad embarrassed the board members to an extent that they adopted many of the proposals advocated by shareholder activists (Monks and Minnow, 1995; Dyck and Zingales, 2002). Similarly, as is indicated earlier, numerous expropriation practices (for example SK Telecom) were stopped in emerging markets not because of court interventions but through dissemination of diversionary behavior via media. In addition, anecdotal evidence also suggests that public humiliation is used by regulators in emerging markets to discipline firms. In Hong Kong, for example, the main sanctions available to regulators are not financial penalties, but the use of publishing names of those who violate listing requirements through the press. Another important channel used by media to discipline managers is by influencing politicians. Media's attention on corporate issues can drive politicians to enact and enforce laws because of the fear that their inability to respond to corporate issues may hurt their political careers in future (Dyck and Zingales, 2002).

Given media's impact on firm's governance and information environment, it is intuitive to argue that it should also have an impact of firm's dividend policies. Prior literature suggests a strong link between corporate 
governance and firm's dividend policies. Jiraporn et al. (2008), for example, argue that effective governance mechanisms allow shareholders to force management to disgorge cash and pay dividends. This strand of literature suggests that dividend policy of a firm is a function of the strength of shareholders rights (La Porta et al., 1998). Effective shareholders rights can discipline managers by providing shareholders with power to replace directors, sue directors, and liquidate firm to receive proceeds. This strand of literature believes that power of shareholders over management induces managers to pay dividends. Another factor that causes firms to pay high dividends in emerging markets is their concern for reputation. Prior literature suggests that firms and managers use dividends to establish a reputation for decent treatment of minority shareholders (Easterbook, 1984). Better reputation allows them with easy access to capital in future. We believe that managers want themselves to be seen as those entities that can raise capital easily and at a competitive rate. By paying high dividends, they ensure that whenever need for capital arise, they are in a better position to raise it. This paper, therefore, hypothesizes that media plays an important role in improving governance, and thereby resulting in high dividends, by affecting the reputation of firms and managers and by strengthening shareholders rights by pressurizing management. However, this effect of media on governance mechanisms and, eventually, on dividend policies can only happen if media is independent. Independent media helps in gathering, verifying, and disseminating reliable and objective information. It ensures that deceitful behavior of management, if it ever happens, does not remain unnoticed. Failure to perform these tasks can minimize the disciplining role of media.

H1a: Firms headquartered in countries with more independent media pay high dividends than firms headquartered in countries with less independent media.

In contrast to the arguments presented above, there is a competing strand of literature that suggests the opposite. This strand of literature argues that dividend policy is a signalling device used by managers to reduce information asymmetries. Grossman and Hart (1980), for instance, document that high dividend payouts alleviate agency conflicts through the reduction of free cash flow available to managers. They argue that paying high dividends reflect managements' good faith and signal low agency problems. In another related study, Jensen (1986) concludes that high payout ratio lessens the agency costs by reducing free cash flows that can be expensed on unprofitable projects. According to this school of thought, if media reduces information asymmetries by improving governance and information environment of a firm, there is lesser need on part of firms to use dividend policy as a signaling device. Therefore, we argue that firms operating in countries with more independent media are less likely to pay high dividends relative to firms operating in countries with less independent media.

H1b: Firms headquartered in countries with more independent media pay less dividends than firms headquartered in countries with less independent media.

\section{DATA}

This paper documents the relationship between media independence and dividend policies of firms in twenty three emerging stock markets from various parts of the world. The sample contains emerging markets from Latin America (Argentina, Brazil, Chile, Colombia, Peru, Mexico, and Venezuela), Asia-Pacific (Indonesia, Malaysia, Thailand, South Korea, Taiwan, and Philippines), South Asia (India, Pakistan, and Sri Lanka), Europe (Israel, Turkey, Greece, Poland, Czech Republic, Hungary, and Russia), and Africa (South Africa). The sample period for this study is 1999 . The choice of sample period is driven by the availability of data regarding media independence. We describe our dataset in the following subsections.

\subsection{Media independence}

We measure media independence (MEDIA) by the average proportion of market share of private entities in TV and press within a certain country. The data for the proportion of market share of private entities in TV and press is obtained from Shleifer et al. (2003). We use the data provided by Shleifer et al. (2003) to construct a measure for media independence as follows. We believe that if ownership of media is not concentrated in the hands of governments, there is a high probability that it will provide relatively more objective and credible information. A state-owned media is usually more inclined to distort and manipulate information to benefit incumbent politicians, 
prevent voters and consumers from making informed decisions, and ultimately undermine the markets. ${ }^{5}$ Waisboard (1995), while studying the role of media in Latin America, document that government officials benefit more from state-controlled media than the public. We believe that private ownership of media results in provision of alternative views to the public, thereby enabling them to choose among alternatives. It is in contrast to state ownership where only single view is presented to audience. Shleifer et al. (2003), our source of data on media independence, study patterns of media ownership in 97 countries and show that countries that are poorer, more autocratic, and with higher levels of state intervention in the economy also have greater state ownership of the media. They also show that countries with greater state ownership of the media have a less-free press, inferior governance, and lessdeveloped capital markets. Moreover, we also argue that private ownership allows for competition among media firms, thereby ensuring that the public will get unbiased and accurate information. Failing to act responsibly or colluding may harm media's credibility and profitability in the long run.

$$
M E D I A=\frac{1}{2}\left(\begin{array}{l}
\text { Proportion of market share of private entities in TV } \\
+ \text { Proportion of market share of privateentities in Press }
\end{array}\right)
$$

Table 1 documents media independence in each country. The results show that Mexico, Peru, and Turkey are the countries with the most independent media. These countries have a media that is completely owned by private sector. Our results also show that South Africa has the least independent media with only $35 \%$ of the media in the hands of private sector. These results must have changed by now due to privatization and deregulation of media in most of the emerging markets.

Table 1: Descriptive statistics for media independence

\begin{tabular}{lc}
\hline Countries & Media Independence \\
\hline Argentina & 98.00 \\
Brazil & 94.50 \\
Chile & 70.50 \\
Colombia & 86.50 \\
Czech Republic & 83.00 \\
Greece & 80.00 \\
Hungary & 90.00 \\
India & 56.00 \\
Indonesia & 81.00 \\
Israel & 82.00 \\
South Korea & 61.50 \\
Malaysia & 56.50 \\
Mexico & 100.00 \\
Pakistan & 50.00 \\
Peru & 100.00 \\
Philippines & 69.50 \\
Poland & 71.50 \\
Russia & 44.50 \\
South Africa & 35.00 \\
Sri Lanka & 45.00 \\
Taiwan & 68.50 \\
Thailand & 70.00 \\
Turkey & 100.00 \\
Venezuela & 98.50 \\
\hline
\end{tabular}

\footnotetext{
${ }^{5}$ We are aware of the second school of thought - the public interest (Pigouvian) theory. This school of thoughts argues that state ownership of the media (even as a monopoly) is desirable for a number of reasons. First, if consumers are ignorant and if private media outlets serve the ruling elites, then state ownership of media can expose public to less biased, more complete, and more accurate information. Second, information is a public good and once it is supplied to some consumers, it is costly to keep it away from others, even if they have not paid for it. Therefore, government is more suited to own media than private entities.
} 


\subsection{Dividend policy}

We measure dividend policy by two variables: the decision to pay dividend and the dividend payout ratio. Data for dividend policy is obtained from Worldscope. Descriptive statistics for dividend policy is reported in Table 2. The results of Table 2 show that, on average, our sample firms have very low payout ratios. Dividend payout ratios in our sample range from $33.86 \%$ in Chile to $1.10 \%$ in Russia. This result is consistent with prior evidence that shows low dividend payout in emerging market (Aivazian at al., 2003). Our results also show a big variation in the decision whether to pay dividend or not in our sample. On one extreme is India where almost $84 \%$ of firms pay dividends, while on the other extreme is Czech Republic where only $20 \%$ of firms pay dividends.

Table 2: Descriptive statistics for the dividend policy

\begin{tabular}{lcc}
\hline Countries & Decision to Pay Dividend & Dividend Payout Ratio \\
\hline Argentina & 46.34 & 21.08 \\
Brazil & 50.00 & 20.71 \\
Chile & 79.80 & 33.86 \\
Colombia & 60.00 & 30.55 \\
Czech Republic & 20.00 & 15.96 \\
Greece & 78.90 & 24.24 \\
Hungary & 38.89 & 12.15 \\
India & 83.54 & 24.48 \\
Indonesia & 25.84 & 6.88 \\
Israel & 58.70 & 24.54 \\
South Korea & 49.72 & 7.81 \\
Malaysia & 57.19 & 13.46 \\
Mexico & 26.25 & 6.84 \\
Pakistan & 59.21 & 23.73 \\
Peru & 45.00 & 22.23 \\
Philippines & 22.14 & 6.22 \\
Poland & 50.00 & 10.24 \\
Russia & 43.75 & 1.10 \\
South Africa & 51.87 & 16.34 \\
Sri Lanka & 73.68 & 28.38 \\
Taiwan & 24.75 & 9.33 \\
Thailand & 31.88 & 12.90 \\
Turkey & 57.50 & 18.04 \\
Venezuela & 57.14 & 28.86 \\
\hline
\end{tabular}

\section{METHODOLOGY}

The most obvious question for this study is to test whether media independence is related to a firm's choice of dividend policy. We do so by estimating a cross-sectional regression with dividend policy (DP) as dependent variable and media independence (MEDIA) as an independent variable. Mindful of the effects that firm-specific characteristics may have on dividend policy, we also add a couple of firm-specific variables in our regression equation. For example, larger firms generate more interest from stock market participants and therefore have better information environment. As a result, they are more inclined to pay dividends (Deshmukh, 2003; Fama and French, 2001). Therefore, we add log of firm's market capitalization (SIZE) to capture the effect of size on dividend policy. We also add total debt to total asset ratio (LEVERAGE) to capture the effect of leverage on dividend policy of a firm. Prior literature suggests negative relationship between leverage and dividend policy (Rozeff, 1982). Similarly, earnings per share (EPS) and sales growth (GROWTH) was added to control for the effect of profitability and growth opportunities on dividend policy. Firms with high growth opportunities tend to pay lower amount of their earnings as dividends, while profitable firms pay higher dividends than other firms (Fama and French, 2001, Aivazian et al., 2003). We will also include industry dummies (IDUM) and region dummies (RDUM) in our regression equation. ${ }^{6}$ For the purpose of completeness, we will estimate our regression equation with and without

\footnotetext{
${ }^{6}$ It is important to mention here that our construction of media variable (MEDIA) is such that we have unique value of media ownership for almost every country in the sample (except Thailand and Peru where $100 \%$ of media is in the hand of private entities). As a result, it is not possible to include country dummies. Therefore, we include region dummies to account for any 
industry and region dummies. ${ }^{7}$ We need to mention here that OLS regression will be used when dividend policy is measured by payout ratios and logistic regression will be used when dividend policy is a decision to pay dividend or not.

$$
\begin{aligned}
& D P=\alpha+\beta_{1}(\text { MEDIA }) \\
& +\beta_{2}(S I Z E)+\beta_{3}(L E V E R A G E)+\beta_{4}(E P S)+\beta_{5}(G R O W T H) \\
& +\sum_{\text {Ind }} \beta^{\text {Ind }}(I D U M)+\sum_{R g} \beta^{R g}(R D U M)+\varepsilon
\end{aligned}
$$

The results of our analysis are reported in Table 3. Interestingly, our results show that firms headquartered in countries with more independent media are less likely to pay dividends than firms headquartered in countries with less independent media. Our logistic regression estimate indicates a significantly negative relationship between decision to pay dividend and media independence. Our results show that odds of paying dividends by firms headquartered in countries with more independent media are 0.0789 [=exp(-2.5390)] times less than firms headquartered in countries with less independent media. ${ }^{8}$ Our results concerning the second proxy for dividend policy, dividend payout ratio, also support our previous findings. Our results show a negative relationship between dividend payout ratios and media independence. We show that for every unit increase in media independence, dividend payout ratio goes down by 11.2611 units. We argue that firms headquartered in countries with relatively more independent media have better information environment than firms headquartered in countries with relatively less independent media. Therefore, these firms - firms headquartered in countries with relatively more independent media - feel lesser need to use dividends as a device to attract investors or to make reputation. Our arguments are consistent with prior literature that argues that dividends can act as information asymmetry reducing device in those regimes where likelihood of expropriation is high. If likelihood that managers will expropriate is low, firms do not feel the need to use dividends as information asymmetry reducing device. We argue that independent media reduces information asymmetries for stock market participants. Therefore, stock market participants in countries with relatively more independent media do not demand high dividends as much as their counterparts in countries with

\begin{tabular}{|c|c|c|c|c|}
\hline \multirow[b]{2}{*}{ Media } & \multicolumn{2}{|c|}{ Decision to Pay Dividend } & \multicolumn{2}{|c|}{ Dividend Payout Ratio } \\
\hline & $-2.3756 * * *$ & $-2.5390 * * *$ & $-6.1692 *$ & $-11.2611^{* * *}$ \\
\hline Size & $0.1070 * * *$ & $0.1594 * * *$ & $0.7603 * * *$ & $1.1396^{* * *}$ \\
\hline Leverage & $-0.0294 * * *$ & $-0.0364 * * *$ & $-0.2192 * * *$ & $-0.2273 * * *$ \\
\hline EPS & 0.0004 & 0.0009 & -0.0139 & -0.0104 \\
\hline Growth & $0.0138 * * *$ & $0.0117 * * *$ & $0.04732 * *$ & 0.0249 \\
\hline Industry Dummies & No & Yes & No & Yes \\
\hline Region Dummies & No & Yes & No & Yes \\
\hline No. of Observations & 1630 & 1630 & 1630 & 1630 \\
\hline Wald-chi ${ }^{2}$ & 199.33 & 304.95 & & \\
\hline Cragg \& Uhler's $\mathbf{R}^{2}$ & 0.185 & 0.301 & & \\
\hline F-value & & & 21.32 & 18.42 \\
\hline Adjusted-R ${ }^{2}$ & & & 0.045 & 0.112 \\
\hline
\end{tabular}
relatively less independent media.

Table 3: Relationship between media independence and dividend policy

effects specific to the geography of firm. We classified our firms to be located in five regions, namely Latin America, AsiaPacific, South Asia, Africa, and Europe. However, due to presence of only one country in Africa, we combined Europe and Africa into one region.

${ }^{7}$ We used robust regression in STATA for all of the regression estimations done in this paper. Robust regression can be used in any situation in which you would use OLS regression. When doing the regression diagnostics, you might discover that one or more data points are outliers. These are points that you have determined are not data entry errors, from a different population than the rest of your data, and for which you have no compelling reason to exclude them from the analysis. Robust regression is a compromise between deleting these points, and allowing them to violate the assumptions of OLS regression.

${ }^{8}$ In other words, our results show that the likelihood of paying dividends by firms headquartered in countries with more independent media is $7.31 \%[=0.0789 /(1+0.0789)]$ less than firms headquartered in countries with less independent media. 


\section{DISCUSSION OF RESULTS}

\subsection{Who effects dividend policy more - TV independence or Press independence?}

Both TV and press can impact the flow of information and therefore information transparency and eventually corporate governance. In order to see whether independence of each of these channels impact firm's choice of dividend policy, we re-estimate Equation (2) by replacing media independence variable by its constituents, i.e. proportion of private share of TV (TV) and proportion of private share of press (PRESS). Modified form of Equation (2) can be written as follows.

$$
\begin{aligned}
& D P=\alpha+\beta_{1}(T V)+\beta_{2}(\text { PRESS }) \\
& +\beta_{3}(S I Z E)+\beta_{4}(\text { LEVERAGE })+\beta_{5}(\text { EPS })+\beta_{6}(\text { GROWTH }) \\
& +\sum_{\text {Ind }} \beta^{\text {Ind }}(I D U M)+\sum_{R g} \beta^{R g}(\text { RDUM })+\varepsilon
\end{aligned}
$$

The results of above equation are reported in Table 4. The results show that independence of both TV and press significantly impact firm's choice of dividend policy. Our results are consistent with the results found in Table 3. An important observation from the results documented in Table 4 is that press independence is relatively more important that TV independence in affecting dividend payout ratios. This result is consistent with prior literature that considers press as more powerful media tool than TV. Afrobarometer (2003) states that "among the various media, newspaper readership is more important...than TV viewing and much more important than radio listening". ${ }^{9}$ In the same report, it mentions that "It (press) is the most effective tool of mass communication for encouraging and reinforcing popular commitments to free speech, the emergence of opinion leadership, the reduction of political fear,

\begin{tabular}{|c|c|c|}
\hline & Decision to Pay Dividend & Dividend Payout Ratio \\
\hline TV & $-0.8427 * * *$ & $-5.7702 * *$ \\
\hline Press & $-3.1980 * * *$ & $-7.7770 *$ \\
\hline Size & $0.1807 * * *$ & $1.0938 * * *$ \\
\hline Leverage & $-0.0369 * * *$ & $-0.2250 * * *$ \\
\hline EPS & 0.0016 & -0.0104 \\
\hline Growth & $0.0124 * * *$ & 0.0198 \\
\hline Industry Dummies & Yes & Yes \\
\hline Region Dummies & Yes & Yes \\
\hline No. of Observations & 1630 & 1630 \\
\hline Wald-chi ${ }^{2}$ & 314.82 & \\
\hline Cragg \& Uhler's $\mathbf{R}^{2}$ & 0.321 & \\
\hline F-value & & 17.41 \\
\hline Adjusted-R ${ }^{2}$ & & 0.110 \\
\hline TV - Press & $2.3553 * * *$ & 2.0068 \\
\hline
\end{tabular}
and open criticism of national broadcasters".

Table 4: Relationship between press and TV independence and dividend policy

\subsection{Which types of firms are affected by media independence?}

An important question arising here is that which types of firms are more affected by media. We argue that firms attracting more interest from stock market participants are the one that are more prone to the effects of media.

\footnotetext{
9 The Afrobarometer is produced collaboratively by social scientists from various African countries. It is coordinated by the Institute for Democracy in South Africa (Idasa), the Centre for Democratic Development (CDD-Ghana), and Michigan State University (MSU) 
Media coverage is, usually, driven by what people want to see. Firms that are too small or are not in the radar of potential investors are not the one where media expend its resources. Firms attracting more investor interest, generally, fall under media scrutiny. Therefore, any effect that media may have of dividend policies should be more pronounced in firms generating significant investor interest. In order to test this conjecture, we divide our sample in different groups based on size, analyst following, ownership concentration, tangibility of assets, and choice of auditors. We believe that firms with bigger size, higher analyst following, ownership concentration, more tangible assets, and big-four auditors will generate more interest from investors and therefore should be affected by media. We re-estimate Equation (2) for each of these groups and report our results in Table 5, Table 6, Table 7, Table 8, and Table 9. ${ }^{10}$ Our results show that firms with large size (Table 5), more analyst following (Table 6), high ownership concentration (Table 7), more tangible assets (Table 8), and big-four auditors (Table 9) are the ones that are affected more by media independence. Our results, consistently, show negative relationship between media independence and dividend polices of firms. For example, we show that media influences dividend policies of only those firms that are audited by one of the big-four auditors. Our results show no impact of media independence on dividend policies of firms that are audited by smaller auditors. The relation between media independence and dividend policies seem to be weaker in firms with smaller size, low analyst following, dispersed ownership, less tangible assets, and non-big-four auditors.

Table 5: Relationship between media independence and dividend policy in sub-samples based on size

\begin{tabular}{|c|c|c|c|c|}
\hline & \multicolumn{2}{|c|}{ Decision to Pay Dividend } & \multicolumn{2}{|c|}{ Dividend Payout Ratio } \\
\hline & Large Firm & Small Firms & Large Firm & Small Firms \\
\hline Media & $-6.0332 * * *$ & -0.6988 & $-29.6056 * * *$ & 5.2306 \\
\hline Size & $0.1377 * * *$ & $0.3798 * * *$ & 0.5738 & $2.7058 * * *$ \\
\hline Leverage & $-0.0388 * * *$ & $-0.0339 * * *$ & $-0.2397 * * *$ & $-0.2248 * * *$ \\
\hline EPS & 0.0017 & $0.1622 *$ & -0.0052 & -0.0090 \\
\hline Growth & $0.0103 * * *$ & $0.0106 * * *$ & -0.0130 & 0.0264 \\
\hline Industry Dummies & Yes & Yes & Yes & Yes \\
\hline Region Dummies & Yes & Yes & Yes & Yes \\
\hline No. of Observations & 743 & 887 & 743 & 887 \\
\hline Wald-chi ${ }^{2}$ & 136.54 & 176.08 & & \\
\hline Cragg \& Uhler's $\mathbf{R}^{2}$ & 0.428 & 0.318 & & \\
\hline F-value & & & 12.13 & 9.65 \\
\hline Adjusted-R ${ }^{2}$ & & & 0.161 & 0.112 \\
\hline
\end{tabular}

Table 6: Relationship between media independence and dividend policy in sub-samples based on analyst following

\begin{tabular}{|c|c|c|c|c|}
\hline & \multicolumn{2}{|c|}{ Decision to Pay Dividend } & \multicolumn{2}{|c|}{ Dividend Payout Ratio } \\
\hline & $\begin{array}{l}\text { High Analyst } \\
\text { Following }\end{array}$ & $\begin{array}{c}\text { Low Analyst } \\
\text { Following }\end{array}$ & $\begin{array}{l}\text { High Analyst } \\
\text { Following }\end{array}$ & $\begin{array}{c}\text { Low Analyst } \\
\text { Following }\end{array}$ \\
\hline Media & $-5.3238 * * *$ & $-3.4485 * * *$ & $-21.5941 * * *$ & -10.2198 \\
\hline Size & 0.0558 & $0.0999 * *$ & 0.6517 & $1.0579 * * *$ \\
\hline Leverage & $-0.0366 * * *$ & $-0.0238 * * *$ & $-0.2340 * * *$ & -0.0842 \\
\hline EPS & -0.0007 & $0.0072 * *$ & -0.0163 & 0.0009 \\
\hline Growth & $0.0079 *$ & $0.0084 * *$ & -0.0068 & -0.0387 \\
\hline Industry Dummies & Yes & Yes & Yes & Yes \\
\hline Region Dummies & Yes & Yes & Yes & Yes \\
\hline No. of Observations & 546 & 432 & 546 & 435 \\
\hline Wald-chi² & 83.00 & 72.83 & & \\
\hline Cragg \& Uhler's R ${ }^{2}$ & 0.369 & 0.299 & & \\
\hline F-value & & & 8.57 & 3.94 \\
\hline Adjusted-R ${ }^{2}$ & & & 0.143 & 0.071 \\
\hline
\end{tabular}

\footnotetext{
${ }^{10}$ We created different groups instead of introducing interaction terms between media and our variables of interest (size, analyst following, ownership concentration, tangibility of assets, and choice of auditors) in regression analysis because interaction terms created high multicollinearity problems.
}

(C) 2012 The Clute Institute http://www.cluteinstitute.com/ 
Table 7: Relationship between media independence and dividend policy in sub-samples based on ownership concentration

\begin{tabular}{|c|c|c|c|c|}
\hline & \multicolumn{2}{|c|}{ Decision to Pay Dividend } & \multicolumn{2}{|c|}{ Dividend Payout Ratio } \\
\hline & $\begin{array}{c}\text { Concentrated } \\
\text { Ownership }\end{array}$ & $\begin{array}{c}\text { Dispersed } \\
\text { Ownership }\end{array}$ & $\begin{array}{c}\text { Concentrated } \\
\text { Ownership }\end{array}$ & $\begin{array}{l}\text { Dispersed } \\
\text { Ownership }\end{array}$ \\
\hline Media & $-.2 .2038 * * *$ & $-3.2846 * * *$ & $-11.4312 * *$ & -13.8766 \\
\hline Size & $0.1884 * * *$ & 0.0719 & $1.2917 * * *$ & 0.5857 \\
\hline Leverage & $-0.0362 * * *$ & $-0.0446 * * *$ & $-0.2239 * * *$ & $-0.2408 * * *$ \\
\hline EPS & 0.0022 & -0.0009 & -0.0040 & -0.0186 \\
\hline Growth & $0.0090 * * *$ & $0.0170 * * *$ & 0.0209 & 0.0074 \\
\hline Industry Dummies & Yes & Yes & Yes & Yes \\
\hline Region Dummies & Yes & Yes & Yes & Yes \\
\hline No. of Observations & 1308 & 319 & 1308 & 319 \\
\hline Wald-chi ${ }^{2}$ & 248.56 & 65.16 & & \\
\hline Cragg \& Uhler's $\mathbf{R}^{2}$ & 0.305 & 0.391 & & \\
\hline F-value & & & 13.22 & 4.73 \\
\hline Adjusted-R ${ }^{2}$ & & & 0.101 & 0.159 \\
\hline
\end{tabular}

Table 8: Relationship between media independence and dividend policy in sub-samples based on tangibility of assets

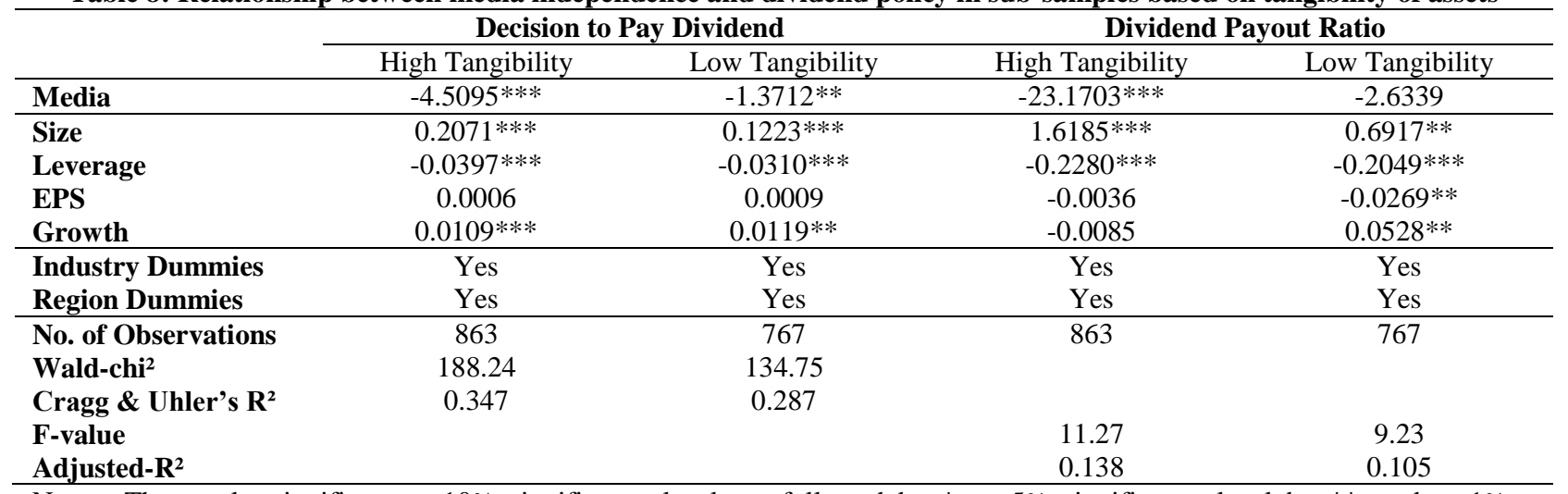

Note: The results significant at $10 \%$ significance level are followed by *, at $5 \%$ significance level by $* *$, and at $1 \%$ a significance level by***.

Table 9: Relationship between media independence and dividend policy in sub-samples based on choice of auditors

\begin{tabular}{|c|c|c|c|c|}
\hline & \multicolumn{2}{|c|}{ Decision to Pay Dividend } & \multicolumn{2}{|c|}{ Dividend Payout Ratio } \\
\hline & Big-four Auditors & Other Auditors & Big-four Auditors & Other Auditors \\
\hline Media & $-3.7812 * * *$ & -1.1366 & $-18.7337 * * *$ & 1.7392 \\
\hline Size & $0.1199 * * *$ & 0.1069 & $1.0397 * * *$ & $1.5436^{* *}$ \\
\hline Leverage & $-0.0350 * * *$ & $-0.0420 * * *$ & $-0.2447 * * *$ & $-0.2112 * *$ \\
\hline EPS & 0.0013 & -0.0002 & -0.0040 & -0.0287 \\
\hline Growth & $0.0132 * * *$ & $0.0178 * * *$ & 0.0355 & 0.0407 \\
\hline Industry Dummies & Yes & Yes & Yes & Yes \\
\hline Region Dummies & Yes & Yes & Yes & Yes \\
\hline No. of Observations & 998 & 201 & 998 & 201 \\
\hline Wald-chi ${ }^{2}$ & 162.54 & 37.55 & & \\
\hline Cragg \& Uhler's $\mathbf{R}^{2}$ & 0.288 & 0.276 & & \\
\hline F-value & & & 12.08 & 3.87 \\
\hline Adjusted-R ${ }^{2}$ & & & 0.137 & 0.094 \\
\hline
\end{tabular}




\section{CONCLUSION}

This paper explores the relationship between media independence and dividend policies in twenty three emerging market from Latin America, Asia-Pacific, South Asia, Africa, and Europe. Our results show negative relationship between media independence and dividend policies of firms. We show that firms headquartered in countries with relatively more independent media not only have lower payout ratios but also have lower likelihood to pay dividends. We argue that firms from countries with relatively more independent media have better information environment than their counterpart firms from countries with relatively less independent media. Therefore, the need to use dividend as an information asymmetry reducing device is less pronounced in these firms, thereby resulting in lower payout ratios and lower likelihood to pay dividends among these firms. Our results also show that press independence exerts more influence on dividend policies than TV independence. Furthermore, our results show that the relationship between media independence and dividend policies is more pronounced in firms that generate greater interest from investors.

\section{AUTHOR INFORMATION}

Omar Farooq is working as an Associate Professor of Finance at Aalborg University, Denmark. Before joining Aalborg University, he has also worked as an Assistant Professor of Finance at Al Akhawayn University in Ifrane, Morocco. His current research focuses is on corporate governance mechanisms in emerging markets, performance of analyst recommendations, and microfinance. E-mail: omar.farooq.awan@gmail.com (Corresponding author)

Salma Dandoune is a graduate student in Corporate Finance at Akhawayn University in Ifrane, Morocco. Her research interest revolves around corporate governance mechanisms in emerging markets. E-mail: s.dandoune@aui.ma

\section{REFERENCES}

1. Afrobarometer, (2003). Freedom of Speech, Media Exposure, and the Defense of a Free Press in Africa.

2. Aivazian, V., Booth, L., and Cleary, S., (2003). Do Emerging Market Firms Follow Different Dividend Policies from U.S. Firms? Journal of Financial Research, 3, pp. 371-387.

3. Bhattacharya, S., (1979). Imperfect Information, Dividend Policy, and "the Bird in the Hand" Fallacy. Bell Journal of Economics, 10, pp. 259-270.

4. Deshmukh, S., (2003). Dividend Initiations and Asymmetric Information: A Hazard Model. Financial Review, 38, pp. 351-368.

5. Dyck, A. and Zingales, L., (2002). Corporate Governance Role of the Media. Working Paper 9309, National Bureau of Economic Research.

6. Dyck, A., Volchkova, N., and Zingales, L., (2007). The Corporate Governance Role of the Media: Evidence from Russia. Working Paper, University of Toronto.

7. Easterbrook, F. H., (1984). Two Agency-Cost Explanations of Dividends. American Economic Review, 74(4), pp. 650-659.

8. Fama, E. F., (1980). Agency Problems and the Theory of the Firm. Journal of Political Economy, 88(2), pp. 288-307.

9. Fama, E. F. and French, K., (2001). Disappearing Dividends: Changing Firm Characteristics or Lower Propensity to Pay? Journal of Financial Economics, 60, pp. 3-43.

10. Fama, E. F. and Jensen, M. C., (1983). Separation of Ownership and Control. Journal of Law \& Economics, 26(2), pp. 301-325.

11. Grossman, S. and Hart, O., (1980). Disclosure Laws and Take-over Bids. Journal of Finance, 35, pp. 323334.

12. Jensen, M. C., (1986). Agency Costs of Free Cash Flow, Corporate Finance, and Takeovers. American Economic Review, American Economic Association, 76(2), pp. 323-329.

13. John, K. and Williams, J. (1985). Dividends, Dilution, and Taxes: A Signaling Equilibrium. Journal of Finance, 40, pp. 1053-1070.

14. Kahan, M. and Rock, E. B., (2007). Hedge Funds in Corporate Governance and Corporate Control. University of Pennsylvania Law Review, 155. 
15. Kowalewski, O., Stetsyuk, I., and Talavera, O., (2007). Corporate Governance and Dividend Policy in Poland. Working Paper, Warsaw School of Economics.

16. La Porta, R., Lopez-de-Silanes, L., Shleifer, A., and Vishny, R., (1998). Law and Finance. Journal of Political Economy, 106, pp. 1113-1155.

17. La Porta, R., Lopez-de-Silanes, F. Shleifer, A., and Vishny, R., (2000). Agency Problems and Dividend Policies around the World. Journal of Finance, 55(1), pp. 1-33.

18. Miller, M. H. and Rock, K., (1985). Dividend Policy under Asymmetric Information. Journal of Finance, 40, pp. 1031-1051.

19. Monks, R. and Minow, N., (1995). Corporate Governance. Blackwell Publishers: Cambridge, MA.

20. Myers, S., (2000). Outside Equity. Journal of Finance, 55(3), pp. 1005-1037.

21. Jiraporn, P., Kim, J-C, and Kim, Y. S. K., (2008). Dividend Policy and Corporate Governance Quality. Working Paper, Pennsylvania State University

22. Rozeff, M., (1982). Growth, Beta and Agency Costs as Determinants of Dividend Payout Ratios. Journal of Financial Research, 5(3), pp. 249-259.

23. Shleifer, A., Djankov, S., McLiesh, C., and Nenova, T., (2003). Who Owns the Media? Journal of Law and Economics, 46, pp. 341-382.

24. Waisbord, S., (1995). Leviathan Dreams: State and Broadcasting in South America. The Communication Review, 1(2), pp.201-226

25. Zingales, L., (2000). In Search of New Foundations. Journal of Finance, 55, pp. 1623- 1653. 